\title{
Management's Duty to Back Up Competitive Disadvantage Claims
}

\author{
Neil Lloyd $\dagger$
}

The National Labor Relations Act ("NLRA") requires that employers bargain collectively with the authorized representatives of their employees. ${ }^{1}$ The statute mandates bargaining over "wages, hours, and other terms and conditions of employment," and, more problematically, requires that the parties bargain in "good faith." While agreeing on broad principles, the courts and the National Labor Relations Board ("the Board") have struggled to identify what "good faith" requires in individual cases. For decades, courts have disagreed about whether an employer acts in bad faith when it refuses to back up its claim that paying a particular wage would place it at a "competitive disadvantage."3 At the heart of this disagreement lies an employer's reluctance to disclose financial information to the union. ${ }^{4}$

$\dagger$ B.A. 1988, Pomona College; J.D. Candidate 1994, The University of Chicago.

1 Pub L No 74-198, 49 Stat 499 (1935), codified as amended at 29 USC $\$ \S 151-69$ (1988). Section 8(a)(5) of the NLRA provides: "It shall be an unfair labor practice for an employer ... to refuse to bargain collectively with the representatives of his employees." 29 USC \& 158(a)(5).

2 Section $8(d)$ of the NLRA defines collective bargaining as:

the performance of the mutual obligation of the employer and the representative of the employees to meet at reasonable times and confer in good faith with respect to wages, hours, and other terms and conditions of employment ... but such obligation does not compel either party to agree to a proposal or require the making of a concession.

29 USC § 158(d).

3 Compare NLRB $v$ Western Wirebound Box Co., 356 F2d 88 (9th Cir 1966); K-Mart Corp. $v$ NLRB, 626 F2d 704 (9th Cir 1980) (competitive disadvantage claims must be substantiated), with United Fire Proof Warehouse v NLRB, 356 F2d 494 (7th Cir 1966); NLRB v Harvstone Manufacturing Corp., 785 F2d 570 (7th Cir 1986); Nielsen Lithographing Co. $v$ NLRB, 854 F2d 1063 (7th Cir 1988) ("Nielsen P"); Graphic Communications Local 508 (Nielsen Lithographing) v NLRB, 977 F2d 1168 (7th Cir 1992) ("Nielsen II") (no duty to substantiate competitive disadvantage claims).

1 In this Comment, "financial information" includes information used by management to predict future economic performance. Examples include:

an employer's assessment of the company's health, detailed production and sales data, information about products and inventory, techniques and processes used by the employer, long-range forecasts of growth or contraction, and detailed breakdowns of the employer's financial posture (expanding the financial reports ordinarily available to shareholders). 
The Board and the courts have long held that employers act in bad faith when they refuse to give unions "relevant information needed by a labor union for the proper performance of its duties." ${ }^{n 5}$ And in NLRB $v$ Truitt Manufacturing Co., the Court held that financial information could be relevant and necessary if management claimed it was unable to pay a particular wage. ${ }^{6}$ In other words, unsubstantiated "inability-to-pay" claims can in themselves constitute bad faith. ${ }^{7}$ Whether an employer's competitive disadvantage claims should be treated in the same way is a separate question, though Truitt can be read to suggest as much. $^{8}$

The Board, however, presently treats inability-to-pay and competitive disadvantage claims as "analytically distinct," requiring substantiation in the former case, but not the latter. ${ }^{9}$ Inability-to-pay claims can range from relatively subtle statements such as "the Company 'couldn't reach' the Union's wage proposal,",10 to transparent pleas of poverty. ${ }^{11}$ Competitive disadvantage

Note, Substantiating “Competitive Disadvantage" Claims: A Broad Reading of Truitt, 87 Mich L Rev 2026, 2028 n 14 (1989), citing Leslie K. Shedlin, Regulation of Disclosure of Economic and Financial Data and the Impact on the American System of Labor-Management Relations, 41 Ohio St L J 441, 445-46 (1980). Although wage rates enter into any such calculation, the union has the right to such information because of the impracticability of asking each member what his or her wages are and compiling this information independently. See note 30 and accompanying text.

5 Detroit Edison Co. $v$ NLRB, 440 US 301, 303-04 (1979); NLRB v Acme Industrial Co., 385 US 432, 435-36 (1967).

651 US 149, 152-53 (1956).

7 Id at 153.

8 See id at 153-54.

9 See United Steelworkers Local 14534 v NLRB, 983 F2d 240, 244 (DC Cir 1993) ("Local 14534"). For nearly twenty-five years the Board treated competitive disadvantage and inability to pay claims similarly. See, for example, Nielsen Lithographing Co., 279 NLRB 877 (1986). In 1988, the Seventh Circuit remanded Nielsen to the Board to reconsider its position on competitive disadvantage claims. Nielsen I, 854 F2d at 1065. On remand, the Board reversed its position, and adopted the Seventh Circuit's. Nielsen Lithographing Co., 305 NLRB 679 (1991), aff'd, Nielsen II, 977 F2d at 1168.

Although beyond the scope of this Comment, the Board's reversal raises interesting administrative law issues. The Second, Seventh, and D.C Circuits have deferred to the new standard, although it is based on the Board's interpretation of Truitt, rather than the NLRA. See Nielsen, 305 NLRB at 699-700. The Second Circuit recently stated:

Recently, however, the Board has altered its reading of Truitt.... Although the

[Nielsen] opinion may not be as reasoned as we might wish and is a reading of Truitt we do not entirely share, we must "uphold a decision of less than ideal clarity if the agency's path may reasonably be discerned."

Torrington Extend-A-Care Employee Ass'n v NLRB, 1994 US App LEXIS 3646 at *19-23 (2d Cir Feb 28, 1994), quoting Motor Vehicles Manufacturers Ass'n v State Farm Mutual Insurance Co., 463 US 29, 43 (1983) (emphasis added).

${ }_{10}$ New York Printing Pressman \& Offset Workers Union No. 51 v NLRB, 538 F2d 496, 500 (2d Cir 1976).

11 See, for example, Drivers, Warehouse \& Dairy Employees Local $75 v$ NLRB, 866 
claims, by contrast, link wage positions with financial status without asserting that the employer is literally unable to pay the wage. Thus, it might be difficult, rather than impossible, to pay a proposed wage. Examples include claiming a "cut was necessary because of price cutting indulged in by competition"12 and "seeking [ ] concessions to increase [] competitive standing."

Employers have fought to maintain this distinction through a narrow interpretation of Truitt, fearing that disclosure of financial information outside of inability-to-pay cases would both threaten confidentiality and encourage unions to second-guess management decisions. Under this view, referred to here as the Harvstone/Nielsen doctrine, employers need only back up inability-to-pay claims and not competitive disadvantage claims. ${ }^{14}$ In contrast, unions, fearing that they will be unable to bargain effectively and responsibly if they must guess whether management is lying, have pushed for a broad interpretation of Truitt. Under this approach, referred to here as the Western Wirebound doctrine, employers must provide the union with information sufficient to verify the accuracy of any competitive disadvantage claim. ${ }^{15}$

Both the narrow and broad interpretations of Truitt purport to advance the underlying policies of the NLRA. The Harvstone/Nielsen doctrine protects management autonomy, ${ }^{16}$ while the Western Wirebound doctrine seeks to improve labormanagement cooperation and the bargaining process. ${ }^{17}$ But both

F2d 1537 (table), 1989 US App LEXIS $1129 * 5-6$ (DC Cir 1989) (“Local 75”); NLRB v Unoco Apparel, Inc., 508 F2d 1368, 1370 (5th Cir 1975) ("The] employees came to the wrong well . . the well is dry."); United Steelworkers Local $5571 v$ NLRB, 401 F2d 434, 436 (DC Cir 1968) ("When the final wage offers were exchanged, the Company returned to its claim that the money to pay for the Union's proposal just wasn't there."). "Although no magic words are required to express an inability to pay, the words and conduct must be specific enough to convey such a meaning." ACL Corp., 271 NLRB 1600, 1602 (1984).

12 Western Wirebound, 356 F2d at 89.

${ }^{13}$ United Paperworkers Intl Union v NLRB, 981 F2d 861, 866 (6th Cir 1992). Other examples are stating that "concessions were needed in order to be competitive' and 'survive in today's market," Local 14534, 983 F2d at 244; making "assertions pertainling] only to declining market conditions attributable to competition from other businesses," id; giving "general evaluations of [ ] long-term financial viability," Local 75, 1989 US App LEXIS 1129 at *6; and supporting a position "on the ground that [the employer] was paying rates in excess of prevailing rates of its competition in the same labor market." Dallas General Drivers, Warehousemen and Helpers, Local $745 v$ NLRB, 355 F2d 842, 845 (DC Cir 1966).

${ }^{14}$ See Harvstone, 785 F2d at 577; Nielsen I, 854 F2d at 1065-66; Nielsen II, 977 F2d at 1170-71.

${ }^{15}$ See Western Wirebound, 356 F2d at 91.

${ }^{16}$ Nielsen II, 977 F2d at 1171.

17 Western Wirebound, 356 F2d at 91. See also First National Maintenance Corp. v 
interpretations push labor-management relations toward extremes. The Harvstone/Nielsen rule allows management to lie with impunity, while the Western Wirebound rule allows unions to second-guess employer decisions and exact unwarranted concessions.

This Comment proposes a third alternative-a "controlled disclosure" rule. Under this rule, management would have to disclose financial information if the Board found substantial evidence that management either lied during bargaining or came to the table unwilling to agree. ${ }^{18}$ This intermediate rule favors neither management nor labor, but seeks to ensure that the process is fair. It requires disclosure in precisely those cases in which management is likely to misuse information, but limits the scope of disclosure and the union's use of the information. Furthermore, because the controlled disclosure standard requires a case-by-case approach, it minimizes the risks of both management and labor abuse-risks invited by the per se approaches of Harvstone/Nielsen and Western Wirebound.

\section{GOOD FAITH AND THE DUTY TO FURNISH INFORMATION}

To determine whether an employer's competitive disadvantage claim is accurate, the union needs access to the employer's financial information. However, the employer's duty to provide this information depends upon whether failing to do so amounts to acting in bad faith. The debate over financial disclosure rules is thus part of the larger debate over good faith generally.

\section{A. The Requirement of Good Faith}

In labor-management relations, the Board and the courts define not only the subjects about which the parties must bargain (terms and conditions of employment), but also how they must bargain (in good faith). Although the meaning of good faith "is not readily ascertainable," ${ }^{\prime 19}$ two general statements can be

$N L R B, 452$ US 666, 678-79 (1981) (stating the NLRA was intended to promote the mutually beneficial resolution of conflicts while preserving management autonomy "to the extent essential for the running of a profitable business").

${ }_{18}$ Under this approach, management would have no duty to substantiate even an inability-to-pay claim made in good faith. Both the Harvstone/Nielsen and the Western Wirebound approaches require management to substantiate all inability-to-pay claims regardless of whether the claims were made in good faith. See Teleprompter Corp. $v$ NLRB, 570 F2d 4, 9 n 2 (1st Cir 1977) (citing cases).

19 Charles J. Morris, ed, 1 The Developing Labor Law 553 (ABA, 2d ed 1983). 
made. First, good faith "is inconsistent with a predetermined resolve not to budge from an initial position. ${ }^{20}$ Second, good faith "necessarily requires that claims made by either bargainer should be honest claims.".21

Good faith in collective bargaining therefore requires that the parties come to the table willing to agree, and that they do not make false claims. However, it does not require that the parties in fact agree, and it does not restrict their ability to posture, change their positions, or be stubborn. The NLRA itself provides that the obligation to bargain collectively "does not compel either party to agree to a proposal or require the making of a concession." 22 To find good or bad faith the Board must examine all of the facts and draw the fine lines separating "puffing" and stubbornness from lying and a predisposition not to agree.

Although the plain language of the NLRA suggests a case-bycase inquiry into good faith in every bargaining dispute, such an approach is not always necessary. ${ }^{23}$ Instead, the Board often employs per se rules, holding that certain actions violate the duty of good faith regardless of their actual purpose. For instance, management would act in bad faith if it refused to bargain with the union for one year after certification, even if it believed in good faith that the union no longer enjoyed majority support. ${ }^{24}$ The dispute over competitive disadvantage claims is essentially about whether a per se rule-either in favor of or against disclosure-or the case-by-case approach is more appropriate.

\section{B. The Duty to Disclose Relevant Information}

Shortly after Congress passed the NLRA in 1935, the Board held, as a corollary to the general duty of good faith, that man-

20 Truitt, 351 US at 154 (Frankfurter concurring in part and dissenting in part); NLRB $v$ Insurance Agents' Int'l Union, 361 US 477, 498 (1960) (stating the duty to bargain collectively requires parties to approach bargaining with "real desire to come into agreement").

21 Truitt, 351 US at 152.

2229 USC \& 158(d).

${ }^{23}$ See id. Section 8(d) requires "the employer and the representative of the employees to meet at reasonable times and confer in good faith with respect to wages, hours, and other terms and conditions of employment ...." As one commentator has noted, "Congress did not give content to these words, leaving the Board and the courts to fill them with meaning." Clyde W. Summers, Harry H. Wellington, and Alan Hyde, Cases and Materials on Labor Law 712 (Foundation Press, 2d ed 1982). Although $\S 6$ gives the Board rulemaking authority, it has typically announced rules in individual cases. See American Hospital Ass'n v NLRB, 499 US 606, 609-10 (1991).

${ }^{24}$ See Brooks v NLRB, 348 US 96, 103 (1954), rule reaffirmed in NLRB v Curtin Matheson Scientific, Inc., 494 US 775, 777 (1990). 
agement had a duty to provide the union with relevant information. $^{25}$ This requirement implies three related propositions. First, management has the right to keep irrelevant information from the union. Second, the union has the right to inspect any and all relevant information in management's possession. And third, management's refusal to supply such information constitutes a failure to bargain in good faith. ${ }^{26}$

The Supreme Court has described relevant information as that which is "needed by the bargaining representative for the proper performance of its duties."27 However, the union can generally show "necessity" under a lenient standard similar to that afforded civil litigants in discovery. In NLRB $v$ Acme Industrial Co., the Court held that the Board properly ordered disclosure of information "acting upon the probability that the desired information was relevant, and that it would be of use to the union in carrying out its statutory duties and responsibilities."28 Under this standard, the union is entitled to information that would be useful in developing its bargaining positions, and in evaluating management's positions, even if the information is not strictly necessary for bargaining to go forward. ${ }^{29}$

As with good-faith inquiries generally, the Board here employs per se rules, holding that certain information is so essential that its relevance need not be reestablished in each case. Information about wages paid to individual employees is a relatively straightforward example. ${ }^{30}$ The union is entitled to such information on demand without showing why it would be necessary.

${ }_{25}$ See Pioneer Pearl Button Co., 1 NLRB 837, 842-43 (1936). See also NLRB v Acme Industrial Co., 385 US 432, 435-36 (1967); Nielsen II, 977 F2d at 1170 (stating the union is entitled to information "as a corollary of the statutorily protected right of collective bargaining”), citing NLRB v Burkart Foam, Inc., 848 F2d 825, 833 (7th Cir 1988).

${ }_{26}$ Truitt, 351 US at 152-53.

${ }^{27}$ Acme Industrial, 385 US at $435-36$.

${ }^{28}$ Id at 437 (describing this as a "discovery-type standard").

29 Federal Rule of Civil Procedure 26(b)(1) provides:

Parties may obtain discovery regarding any matter, not privileged, which is relevant to the subject matter involved in the pending action .... The information need not be admissible at trial if the information sought appears reasonably calculated to lead to the discovery of admissible evidence.

FRCP 26(b)(1) (emphasis added).

${ }^{30}$ See Whitin Machine Works, 108 NLRB 1537, 1538-39 (1954), enf'd, 217 F2d 593 (4th Cir 1954). See also NLRB v F.W. Woolworth Co., 352 US 938 (1956) (per curiam) (Under the circumstances in this case, "failure to furnish the wage information constituted an unfair labor practice."). Another example is the number of hours each employee in the bargaining unit has worked. Morris, The Developing Labor Law at 624-25 (cited in note 19) ("Items of information related to hours, and other terms and conditions of employment' have been ordered disclosed on the same basis as wage information."). 
For other types of information, the union must show necessity in a particular context. For example, the union is entitled to information about time-study data when the piece rate for certain jobs is at issue, but not as a matter of course. ${ }^{31}$

If management does not voluntarily comply with a union's request for relevant information, the Board can require disclosure..$^{32}$ By asserting countervailing interests such as confidentiality, employers sometimes successfully avoid disclosure-even when the union has a legitmate interest in the information. ${ }^{33}$ However, the union's right to relevant information often outweighs such employer concerns. ${ }^{34}$

\section{Financial INFORMation and MANAGEMENT AUtonomy}

"Financial information" has historically received greater protection from disclosure than have other types of information. ${ }^{35}$ Accordingly, it has only been considered relevant in limited circumstances. Courts have not applied the usefulness standard used in other information-disclosure cases when reviewing union demands for financial information. ${ }^{36}$ In fact, until Truitt, the circuit courts had split on whether an employer ever had a duty to disclose such information, despite its obvious usefulness to the union. ${ }^{37}$ In Truitt, the Court held that an employer could be required to disclose financial information to back up an inability-to-pay claim. ${ }^{38}$

31 See J.I. Case Co. v NLRB, 253 F2d 149, 154-55 (7th Cir 1958).

32 "The Board is empowered ... to prevent any person from engaging in any unfair labor practice affecting commerce." 29 USC $\S 160$ (a). See also Truitt, 351 US at 152; Teleprompter Corp. $v$ NLRB, 570 F2d 4, 10 (1st Cir 1977).

${ }_{33}$ See, for example, Detroit Edison Co. $v$ NLRB, 440 US 301, 314-17 (1979) (holding the employer's interest in protecting the identity of employment aptitude test takers outweighed the union's right to relevant information).

${ }^{34}$ See, for example, Curtiss-Wright Corp. $v$ NLRB, 347 F2d 61, 71 (3d Cir 1965) (holding relevance outweighed the employer's confidentiality concerns); Olivetti Office U.S.A., Inc. $v$ NLRB, 926 F2d 181, 188-89 (2d Cir 1991) (holding the employer's confidentiality interest did not outweigh the union's right to relevant information where the union assured the company that all disclosed data would remain confidential).

${ }_{35}$ See note 4 for the definition of financial information.

${ }^{36}$ See Teleprompter, 570 F2d at 11 (holding that the "discovery" rule is not tailored to inability-to-pay cases and that the union is entitled only to that information reasonably necessary to substantiate the employer's claim).

${ }_{37}$ Compare NLRB v Truitt Manufacturing Co., 224 F2d 869, 874 (4th Cir 1955) (no duty to disclose financial information), rev'd, 351 US 149 (1956), with NLRB $v$ Jacobs Manufacturing Co., 196 F2d 680, 684 (2d Cir 1952) (financial information must be disclosed to substantiate certain employer claims).

${ }^{38} 351$ US at 152-53. However, the Court did not apply a per se rule to inability-topay claims. See text accompanying note 55 . 
The dispute over competitive disadvantage claims persists because the scope of the so-called Truitt duty remains unclear. The Court has neither specified which types of claims must be substantiated nor identified particular circumstances in which substantiation is required. However, courts generally agree that financial information becomes relevant only when employers base certain claims on such information. ${ }^{39}$ That the information may be useful for developing union negotiation positions in a general sense does not make it relevant. Instead, financial information is relevant only if it enables the union to verify the employer's claim. ${ }^{40}$

To set a standard for when employers must back up competitive disadvantage claims, courts must not only resolve the scope of employers' Truitt duties, but must also determine whether these duties conflict with those the Supreme Court articulated in First National Maintenance Corp. $v$ NLRB. ${ }^{41}$ The First National Maintenance Court held that "management decisions" are generally not mandatory subjects for bargaining. ${ }^{42}$ Recently, the Seventh Circuit cited First National Maintenance to support the Harustone/Nielsen rule that competitive disadvantage claims need not be substantiated. ${ }^{43}$ Other courts-ignoring the possible importance of First National Maintenance-have held that Truitt does extend to competitive disadvantage claims. ${ }^{44}$

\section{A. NLRB v Truitt}

In Truitt, the Supreme Court upheld the Board's determination that an employer's failure to disclose financial information supporting its inability-to-pay claim constituted a failure to bar-

${ }^{39}$ See Teleprompter, 570 F2d at 11 \& n 3. Although the Court endorsed the discovery standard several years after Truitt in Acme Industrial, 385 US at 437, see text accompanying notes 27-29, it did not purport to expand Truitt's narrower duty to substantiate financial information. But see Summers, et al, Labor Law at 685 (cited in note 23), implying that the Acme Industrial discovery standard should apply to financial information. Under.this standard, the union's request, not the employer's claim, would trigger the duty to disclose. Research reveals no court that has ever endorsed this reading of Acme Industrial.

40 Robert A. Gorman, Basic Text on Labor Law, Unionization and Collective Bargaining 413 (West, 1976) (stating an employer's assertion of poverty makes financial information relevant). See also Truitt, 351 US at 152 (noting the Board could find that the failure to substantiate a claim constituted a refusal to bargain in good faith).

41452 US 666 (1981).

42 Id at 676-77.

${ }^{43}$ See Nielsen II, 977 F2d at 1170-71.

44 See, for example, NLRB v Sioux City Stockyards, 901 F2d 669, 669-70 (8th Cir 1990) (per curiam). 
gain in good faith. ${ }^{45}$ During bargaining, the union asked for a wage increase of 10 cents per hour, and the employer countered that anything above 2.5 cents per hour would put it out of business. ${ }^{46}$ The union asked for some evidence to back up the company's claim. When the employer refused this request, the union asked for "full and complete information with respect to [the company's] financial standing and profits." ${ }^{37}$ The company refused to provide any substantiating information, telling the union, "the information . . . is not pertinent to this discussion and the company declines to give you such information; you have no legal right to such." ${ }^{38}$ The Board found that the employer's failure to back up its claim was an unfair labor practice under $\S$ $8(a)(5)$ and ordered the employer to supply the requested information to the union. ${ }^{49}$

The Fourth Circuit denied enforcement of the Board's order, holding that " $[t]$ he information ... relates to matters altogether in the province of management, which were not the proper subject of bargaining." Court, the employer in Truitt argued first that "the information requested was irrelevant to the bargaining process," and second that the information "related to matters exclusively within the province of management." 51 The Court disagreed. In enforcing the Board's order it stated:

Good-faith bargaining necessarily requires that claims made by either bargainer should be honest claims. This is true about an asserted inability to pay an increase in wages. If such an argument is important enough to present in the give and take of bargaining, it is important enough to require some sort of proof of its accuracy. ${ }^{52}$

The Court noted that the Board's policy of requiring substantiation in similar cases had started as early as one year after the

15351 US at 149.

46 Id at 150.

47 Id.

48 Id at 150-51.

49 Id at 151.

50 Truitt, 224 F2d at 874. The Fourth Circuit thus implied that disclosure of this information would lead to bargaining about non-mandatory subjects. In another case, the Second Circuit had enforced a similar order. Jacobs, 196 F2d at 682. The Jacobs court held that an employer's refusal to back up its "bare assertion" of inability to pay violated the duty of good faith. Id at 683.

31 US at 151.

S2 Id at 152-53. 
passage of the NLRA in Pioneer Pearl Button Co. ${ }^{53}$ There, the Board had held that an employer failed to bargain in good faith when it "did no more than take refuge in the assertion that [its] financial condition was poor." However, instead of adopting the Board's implied presumption of bad faith from Pioneer Pearl Button, the Truitt Court required a case-by-case determination. The Court stated:

We do not hold, however, that in every case in which economic inability is raised as an argument against increased wages it automatically follows that the employees are entitled to substantiating evidence. Each case must turn upon its particular facts. The inquiry must always be whether or not under the circumstances of the particular case the statutory obligation to bargain in good faith has been met. ${ }^{55}$

The Court did not remand the case to the Board because, the Court found, the Board had not actually employed a per se rule that all inability-to-pay claims be supported. Instead the Board had reached its conclusion that the employer failed to bargain in good faith "under the facts and circumstances of this case."56

Justice Frankfurter and two others concurred in the decision to reverse the Fourth Circuit, but dissented on the ground that by failing to remand, the Court had in effect endorsed a per se rule for inability-to-pay claims. ${ }^{57}$ Despite the Court's explicit denial and Frankfurter's protest, courts endorsing both the Harvstone/Nielsen and Western Wirebound doctrines have in fact held that Truitt did endorse such a per se rule, at least for inability-to-pay claims. ${ }^{58}$

The Court thus rejected the employer's claim that financial information is irrelevant to bargaining. It is less clear, however,

53 Id at 153, citing Pioneer Pearl Button Co., 1 NLRB 837, 842-43 (1936).

${ }^{54}$ Pioneer Pearl Button Co., 1 NLRB at 843.

55 Truitt, 351 US at 153-54.

56 Id at 153.

${ }^{57}$ Id at 154-55 (Frankfurter concurring in part and dissenting in part) (arguing that a requirement of disclosure any time an employer refused to substantiate a claim of inability to pay would "make a rule of law out of one item-even if a weighty item-of the evidence").

${ }^{58}$ See, for example, Facet Enterprises, Inc. $v$ NLRB, 907 F2d 963, 980 (10th Cir 1990); K-Mart Corp. $v$ NLRB, 626 F2d 704, 707 (9th Cir 1980). For commentary reaching a similar conclusion, see Archibald Cox, The Duty to Bargain in Good Faith, 71 Harv L Rev 1401, 1430 (1958) (arguing that Truitt announced a per se rule); Comment, The Encouragement of Labor-Management Cooperation: Improving American Productivity Through Revision of the National Labor Relations Act, 40 UCLA L Rev 571, 624 n 242 (1992) (noting that Truitt has been applied as a per se rule). 
whether the Court disputed the Fourth Circuit's assertion that some information is "exclusively within the province of management." ${ }^{.59}$ The Court did not distinguish between information that is itself within the exclusive province of management and information that relates to matters that are within such a province. However, it is quite reasonable to assume that information could relate to matters within the exclusive province, but not be shielded from disclosure if management used it to make false claims. In any case, if there is such a province, after Truitt it does not extend to the information necessary to verify potentially false inability-to-pay claims.

\section{B. First National Maintenance Co. $v$ NLRB}

First National Maintenance involved a more basic question: whether an employer has any duty to bargain at all over certain decisions. The Court held that the Board had exceeded its authority by interpreting "terms and conditions of employment"-about which management must bargain-to include management's decision to close part of a business. ${ }^{60}$ First National Maintenance, a cleaning services company, decided not to renew a service contract with one of its customers after the customer insisted on a lower price. ${ }^{61}$ Although the employer claimed it was closing that part of its business "purely [as] a matter of money," complications arose because the employees terminated as a result of the cancellation had recently voted to unionize. ${ }^{62}$ The union requested that the employer bargain about its decision not to renew the contract, and when the employer refused, the union filed an unfair labor practice charge. ${ }^{63}$

The Board held that even if the employer had based its decision on purely financial considerations, it still had a duty to bargain about the decision itself. ${ }^{64}$ The Second Circuit affirmed but

59 Truitt, 351 US at 151.

60 452 US 666 (1980).

61 Id at 669-70.

62 Id. The NLRA prohibits employers from closing a part of a business because employees have unionized. Textile Workers Union v Darlington Manufacturing Co., 380 US 263, 274-75 (1965). Even though a union is not entitled to bargain about a decision to partially close a facility, the Board can require the employer to reinstate the affected employees if the employer's decision was made with anti-union animus. First National Maintenance, 452 US at 682 . See also 29 USC $\S 160$ (c).

63 452 Us 669-70.

64 First National Maintenance Corp., 242 NLRB 462, 465 (1979). The Board endorsed the Administrative Law Judge's determination that an employer with a unionized work force who wishes to alter its hiring arrangements must discuss the decision with the 
stated that the Board's per se rule was inappropriate..$^{65}$ Instead, it held that the NLRA creates a rebuttable presumption in favor of mandatory bargaining. ${ }^{66}$

The Supreme Court reversed and announced its own test in the process. The Court stated that " $[\mathrm{m}]$ anagement must be free from the constraints of the bargaining process to the extent essential for the running of a profitable business." these concerns about management autonomy, the Court held that management decisions were presumptively not mandatory bargaining subjects. Instead, it held that bargaining "over management decisions that have a substantial impact on the continued availability of employment should be required only if the benefit, for labor-management relations and the collective bargaining process, outweighs the burden placed on the conduct of the business." ${ }^{28}$ The Court premised this balancing test on the rationale that subjects should be mandatory, rather than permissive, only if mandatory bargaining fostered the neutral resolution of conflicts. ${ }^{69}$

Applying its test, the Court found that requiring management to bargain about "decision[s] ... akin to the decision whether to be in business at all" imposed a substantial burden. ${ }^{70}$ On the other hand, the potential benefit to the union was slight. The Court stated that "[t]he union's practical purpose in participating [ ] will be largely uniform: it will seek to delay or halt the closing." The Court thought that it was "unlikely ... that requiring bargaining over the decision itself, as well as its effects, will augment th[e] flow of information or suggestions" to management; such a requirement would therefore not "foster in a neutral manner a system in which the conflict between [labor and management] may be resolved."72

union, whether the reason is "lack of money or a mere desire to become richer." Id at 465.

${ }_{65}$ NLRB $v$ First National Maintenance Corp., 627 F2d 596, 601-02 (1980).

66 Id at 601.

${ }^{67}$ First National Maintenance, 452 US at 678-79.

68 Id at 679.

69 Id at 678 (" $[\mathrm{M}]$ andatory bargaining is premised on the belief that collective discussion backed by the parties' economic weapons will result in decisions that are better for both management and labor.”). Justices Brennan and Marshall argued in dissent that the Court's balancing test did not foster such a neutral resolution because it took account only of management's interest. Id at 689-90 (Brennan dissenting).

70 Id at 677.

71 Id at 681 .

72 Id at $680-81$. 
The Court distinguished its ruling in First National Maintenance from Fibreboard Paper Products Corp. $v N L R B$, in which it had required management to bargain about its decision to subcontract work previously done by unionized employees. ${ }^{73}$ In that case, "a desire to reduce labor costs ... was at the base of the employer's decision to subcontract."74 The Fibreboard Court found this desire "peculiarly suitable for resolution within the collective bargaining framework," noting that the decision "did not alter the [c]ompany's basic operation." Such bargaining, the Fibreboard Court had concluded, "would not significantly abridge [the employer's] freedom to manage the business."77

The First National Maintenance Court explicitly limited its decision: "In this opinion we of course intimate no view as to other types of management decisions, such as plant relocations, sales, other kinds of subcontracting, automation, etc., which are to be considered on their particular facts. ${ }^{\prime 78}$ The Court neither discussed nor even cited Truitt, although both opinions address the NLRA's limits on management autonomy and seem to reach divergent conclusions. Truitt requires an employer to disclose financial information when asserting inability to pay, while First National Maintenance excuses the employer from even having to bargain over certain management decisions, let alone having to disclose information. ${ }^{79}$

The tension between First National Maintenance and Truitt becomes quite evident when one considers that an inability to pay arguably represents the most essential of management decisions. Indeed, the First National Maintenance Court's holding that management must be "free from the constraints of the bargaining process to the extent essential for the running of a profitable business" ${ }^{\prime 80}$ bears a striking resemblance to the Fourth

73379 US 203 (1964).

74 First National Maintenance, 452 US at 680, citing Fibreboard, 379 US at 213-14.

${ }^{75}$ Fibreboard, 379 US at 214.

76 Id at 213.

77 Id. This Comment does not discuss whether the Court's attempt to distinguish Fibreboard is particularly persuasive. For present purposes, the lesson of the cases lies in the logic that if labor costs are the reason behind the employer's decision, the employer will more likely be required to bargain about the decision.

${ }^{78}$ First National Maintenance, 452 US at $686 \mathrm{n} 22$ (emphasis added). See also id at 687 ("In order to illustrate the limits of our holding, we turn to the specific facts of this case.").

${ }_{79}$ Only two cases relevant to this discussion incorporate both opinions. See Olivetti Office U.S.A., Inc. v NLRB, 926 F2d 181, 186, 188 (2d Cir 1991); Nielsen II, 977 F2d at 1169-70.

80452 US at $678-79$. 
Circuit's holding in Truitt that financial information concerned matters within the "province of management" the Truitt Court implicitly rejected. By seemingly contradicting Truitt, First National Maintenance further complicates the question of how competitive disadvantage claims should be treated.

\section{Competitive Disadvantage Claims in the Circuit COURTS}

Until the Seventh Circuit's Nielsen II decision, which explicitly relied on First National Maintenance, courts based the duty to disclose financial information on differing interpretations of Truitt. One line of cases reads Truitt to require employers to substantiate any competitive disadvantage claim. The other line has taken the opposite view, holding that management need back up only inability-to-pay claims. This Section describes both interpretations and discusses their persuasiveness.

\section{A. Western Wirebound: The Broad Disclosure Standard}

In NLRB $v$ Western Wirebound Box Co., the Ninth Circuit applied Truitt beyond inability-to-pay claims by enforcing a Board order requiring an employer to back up its competitive disadvantage claim. ${ }^{82}$ The Western Wirebound doctrine embodies the principle that in order to ensure fair collective bargaining, the union must be able to evaluate management's claims. ${ }^{83}$ As one commentator has argued, "the nature of the employer's claim is irrelevant; the important principle is that an employer must prove what it claims." that in both inability-to-pay and competitive disadvantage cases, "the give-and-take of collective bargaining is hampered and ren-

$81224 \mathrm{~F} 2 \mathrm{~d}$ at 874.

82 356 F2d 88, 91 (9th Cir 1966).

Bs Id at $90-91$.

${ }^{84}$ Note, 87 Mich L Rev at 2035 (cited in note 4). Several courts and commentators have endorsed the Western Wirebound approach. Cases include New York Printing Pressmen \& Offset Workers Union No. $51 v$ NLRB, 538 F2d 496 (2d Cir 1976); Sioux City Stockyards, 901 F2d at 669-70; K-Mart Corp v NLRB, 626 F2d 704 (9th Cir 1980). For additional favorable commentary, see John Gaal, The Disclosure of Financial Information: Competitiveness and the Current Requirements of The Duty to Bargain in Good Faith, 38 Labor L J 562, 569-71 (1987); Florian Bartosic and Roger C. Hartley, The Employer's Duty to Supply Information to the Union-A Study in the Interplay of Administrative and Judicial Rationalization, 58 Cornell L Rev 23, 46 n 97 (1972). 
dered ineffectual when an employer mechanically repeats his claim but makes no effort to produce substantiating data." 85

Proponents of Western Wirebound argue that Truitt's language sweeps far more broadly than the substantiation of the inability-to-pay claim at issue there. For example, the Truitt Court reasoned that if an argument "is important enough to present in the give and take of bargaining, it is important enough to require some sort of proof of its accuracy" and noted that "[g]ood-faith bargaining necessarily requires that claims made by either bargainer should be honest claims." ${ }^{86}$ Further, the Court stated that "[ $t]$ he ability of an employer to increase wages without injury to his business is a commonly considered factor in wage negotiations."

This argument also implies that unverified claims of both competitive disadvantage and inability to pay similarly undermine the bargaining process. ${ }^{88}$ Thus, although the Truitt Court focused primarily on the employer's conduct, Western Wirebound proponents argue that it was concerned not with such conduct in the abstract, but rather with the effect such conduct had on the union's ability to bargain. Under this instrumentalist interpretation, the problem with dishonest claims is that they hamper the bargaining process by preventing the union from fully participating. ${ }^{89}$ In short, Western Wirebound uses Truitt to fashion a per se rule that enables the union to make headway in bargaining, not one that simply punishes dishonest employers.

If the Truitt Court was primarily concerned with the effect of unsubstantiated claims on the union's ability to bargain, it also follows that the union should be able to trigger disclosure.

[T] he give-and-take of bargaining . . . [is] rendered less effective by [the employer's] withholding of correlated data from the Union's scrutiny. If the Union cannot meaningfully evaluate the employer's proof, it cannot know whether the company's claims are honest or accurate. ${ }^{90}$

Therefore, the Western Wirebound doctrine requires that employers support their claims, regardless of whether an employer

Bs Western Wirebound, 356 F2d at 91.

Bs Truitt, 351 US at 152-53.

87 Id at 152.

83 Western Wirebound, 356 F2d at 91.

${ }^{89}$ See Note, 87 Mich L Rev at 2050-51 (cited in note 4).

${ }^{90}$ General Electric Co. $v$ NLRB, 466 F2d 1177, 1184 (6th Cir 1972). 
makes a particular claim in good faith. This is essentially a presumption that failing to back up claims amounts to bad faith.

\section{B. Western Wirebound: Carrying Truitt Too Far}

Proponents defend Western Wirebound's per se rule of bad faith on several grounds. First, the rule avoids cumbersome caseby-case inquiries that require the Board and the reviewing court to sift through long records, possibly delaying bargaining for years. ${ }^{91}$ Second, even if such inquiries could be accomplished expeditiously, they involve ascertaining the parties' states of mind-a process that proponents assert inevitably devolves into a search for objective criteria to evaluate the parties' conduct during bargaining. ${ }^{92}$ Reliance on such criteria, they claim, creates the "incongruous result of the NLRB and the courts regulating the manner in which collective bargaining is conducted regardless of the actor's actual state of mind."93 Because the Western Wirebound view focuses on the effect of unsubstantiated claims on the bargaining process, an inquiry into good faith would be unnecessary.

However, all of these arguments ignore the direct conflict between the Western Wirebound doctrine and the reasoning of Truitt itself. The Truitt Court specifically stated that it was not even requiring substantiation of all inability-to-pay claims, ${ }^{94}$ yet proponents of the Western Wirebound doctrine distort Truitt to provide support for their per se rule requiring substantiation of all competitive disadvantage claims. ${ }^{95}$ It is true that lower courts and the Board have uniformly held that Truitt created a per se rule, rather than a presumption, for inability-to-pay claims, ${ }^{96}$ and that the Supreme Court has not overruled any of these seemingly blatant misreadings of Truitt. But neither the fact that many courts have misread Truitt nor the Court's acquiescence in this regard provides a convincing basis for extending these misreadings of Truitt to competitive disadvantage claims.

One commentator has argued that Truitt may actually have required a case-by-case analysis, but claims that finding bad faith based on the failure to back up claims makes sense as a modern

91 See Note, 87 Mich L Rev at 2051 (cited in note 4).

92 Id at 2043-44.

93 Id at 2044, citing Cox, 71 Harv L Rev at 1430 (cited in note 58).

*4 Truitt, 351 US at 153.

95 See, for example, Note, 87 Mich L Rev at 2030.

${ }_{96}$ See note 58. 
rule. ${ }^{97}$ If the effect on the union is the same no matter what the employer intends, so the argument runs, an inquiry into the employer's state of mind would be pointless. ${ }^{98}$ Whether the employer is honest or trying to stall negotiations makes no difference to the union. The effect on the union and the bargaining process is the same regardless of the truth of the claims. ${ }^{99}$

Although this may be true, the argument assumes the bargaining process as a whole would change for the better. The Western Wirebound doctrine fails to acknowledge the risk that unions will misuse financial information. ${ }^{100}$ Such a concern is consistent with the First National Maintenance Court's protection of management autonomy.

\section{Harvstone/Nielsen: The Narrow Disclosure Standard}

In a series of cases beginning in 1966, the Seventh Circuit has interpreted Truitt as requiring that employers need back up only their inability-to-pay claims. ${ }^{101}$ Under this view, the Harvstone/Nielsen doctrine, unless an employer claims inability to pay, it is simply claiming that it does not want to pay, a claim it need not verify. ${ }^{102}$

The Harvstone/Nielsen decisions provide three arguments for reading Truitt narrowly. First, the Supreme Court in Truitt intended only to prevent impermissible threats of bankruptcy, a concern limited to inability-to-pay claims. ${ }^{103}$ Second, competitive disadvantage claims are separately protected as expressions of disagreement under $\S 8(\mathrm{~d})$ of the NLRA. ${ }^{104}$ Finally, even if competitive disadvantage claims are threats, and even if they represent more than simply an unwillingness to reach agreement, they

97 Note, 87 Mich L Rev at 2031-32, 2046-47.

98 Id at 2043-44.

99 Id at 2046.

100 See text accompanying notes 149-53.

101 See Nielsen II, 977 F2d at 1170-71; Nielsen I, 854 F2d at 1065-66; Harustone, 785 F2d at 575; United Fire Proof Warehouse v NLRB, 356 F2d 494, 498 (7th Cir 1966). Recently, the Board and several courts have adopted some variant of this position. See, for example, Washington Materials Inc., 276 NLRB 839, 840 (1985), enf'd in relevant part, 803 F2d 1333 (4th Cir 1986); AMF Bowling Co. $v$ NLRB, 977 F2d 141 (4th Cir 1992); Facet Enterprises, Inc. $v$ NLRB, 907 F2d 963, 980 (10th Cir 1990); Local 14534, 983 F2d 240, 244-45 (DC Cir 1993); United Paperworkers Int'l Union v NLRB, 981 F2d 861 (6th Cir 1992).

${ }_{102}$ See United Fire Proof, 356 F2d at 498.

${ }_{103}$ Nielsen II, 977 F2d at 1170.

${ }^{104}$ See United Fire Proof, 356 F2d at 498; 29 USC § 158(d) (The obligation to bargain collectively in good faith "does not compel either party to agree to a proposal or require the making of a concession."). 
are protected as management "decisions" under First National Maintenance. ${ }^{105}$

\section{Truitt and impermissible threats.}

The Nielsen II court distinguished competitive disadvantage claims from the inability-to-pay claims at issue in Truitt based on the meaning of the claims themselves. The court noted that if the union cannot demand substantiation of inability-to-pay claims, "the employer would have an unfair advantage in bargaining, because it would be making an express or implied threat (of bankruptcy) that the union could not evaluate."106 According to the Seventh Circuit, the Truitt Court was concerned that if such threats could occur,

labor negotiations would involve an even greater element of bluff, guesswork, and sheer gambling than they inevitably do, because the union would be put to the Hobson's choice of acceding to a quite possibly exaggerated claim of poverty or risking its members' jobs. The [Truitt] Court didn't think that forcing the union to play Russian roulette was the epitome of good faith bargaining. ${ }^{107}$

This interpretation of Truitt presumes that the major decision unions need to make is whether to strike or to accede to the employer's demands. ${ }^{108}$ To make this decision, the court reasoned that the union only needs prior assurance that the strike will not be futile. ${ }^{109}$ If the employer can afford higher wages than it claims, however, it would also be more likely to survive a strike and be able permanently to replace union workers. ${ }^{110} \mathrm{Un}$ der this argument, an inability-to-pay claim is improper because the union is forced to decide without complete information. The threat thus improperly limits the union's ability to exercise its right to strike. ${ }^{111}$

In contrast, competitive disadvantage claims create no such problem. Once the employer states that it can pay, the union has

105 See Nielsen $I I, 977$ F2d at 1170.

106 Id.

107 Nielsen I, 854 F2d at 1065.

10 Nielsen $I I, 977$ F2d at 1171.

109 Id.

110 Under the rule in NLRB v MacKay Radio \& Telegraph Co., 304 US 333, 345-46 (1938), an employer may permanently replace striking workers so long as it has not committed an unfair labor practice.

111 Nielsen II, 977 F2d at 1170; Nielsen I, 854 F2d at 1065. 
"all the information it need[s] to decide whether to knuckle under to the company's demands or call a strike."112 So long as the employer is not acting under the "pressure of financial necessity," the union knows that the employer "might bend if the union [can] apply enough countervailing pressure on company profits by striking." 113

2. Competitive disadvantage and the right to disagree.

The Seventh Circuit has explained in several cases that if an employer does not claim inability to pay, it is actually claiming an ability to pay. According to the Harvstone court, "[t]he relevant test [under Truitt] . . . is to ascertain whether the employer said it 'would not' as opposed to 'could not' pay the employees' proposed demands." ${ }^{\text {"14 }}$ Because management can pay the wages requested, a competitive disadvantage claim must mean that it simply does not want to pay them. ${ }^{115}$

According to the Harvstone/Nielsen doctrine, employers who make competitive disadvantage claims without substantiation are simply being stubborn. ${ }^{116}$ Since $\S 8(d)$ of the NLRA protects the right of the parties to disagree, making such a claim without substantiation is not an unfair labor practice. ${ }^{117}$ Moreover, as the court stated in Nielsen I, requiring the employer to back up a "want" is pointless: "A need is objective; it can be substantiated. But how do you substantiate a want? If a company says it wants to make higher profits by reducing its labor costs, what data would falsify its statement?"118

3. Competitive disadvantage claims as management "decisions."

Even if competitive disadvantage claims represent more than disagreement, and even if they are in fact threats similar to inability-to-pay claims, a broad interpretation of First National Maintenance would still excuse management from any obligation

112 Nielsen II, 977 F2d at 1171.

113 Id.

"14 Harvstone, 785 F2d at 575-76, citing United Fire Proof, 356 F2d at 498.

115 Harvstone, $785 \mathrm{~F} 2 \mathrm{~d}$ at 576. "[An] employer operating at a competitive disadvantage [may be] financially able, although perhaps unwilling, to pay increased wages." Id at 577.

${ }^{116}$ Nielsen II, 977 F2d at 1171; United Fire Proof, 356 F2d at 498.

317 Id.

"18 Nielsen I, 854 F2d at 1065. 
to back up such claims. ${ }^{119}$ The distinction between mandatory and permissive bargaining subjects entitles the employer to make certain statements, including (it is argued) competitive disadvantage claims, with impunity. ${ }^{120}$ Because a competitive disadvantage claim concerns a decision about the future of the enterprise, which is generally not a mandatory subject of bargaining, the fact that the employer ties its claim to a negotiating position on wages will not trigger a duty to back up the claim. ${ }^{121}$

In Nielsen II, the court explained, "[t]he company claimed that to stem the hemorrhage of its business it had to cut the compensation of its hourly workers. Well, was that true?"122 The court left this question unanswered, implying that the union had neither a need for nor a right to substantiation. That is, even if the claim were false, the employer would have no duty to back it up. Rather, the union's "right" to substantiation extended only so far as it could force disclosure by use of its power to strike. ${ }^{123}$

To receive First National Maintenance's protection of management autonomy, competitive disadvantage claims must be decisions about which management need not bargain. When an employer claims that it can afford to pay the wages demanded, the argument goes, it is not "in any financial trouble" and is not threatening bankruptcy; it is merely announcing a decision about the scale of operations. ${ }^{124}$ Thus, an employer making a competitive disadvantage claim could only bargain about "whether to shrink its operations." 125

In Nielsen $I I$, the court rejected the notion that the union should have a say in the decision whether to shrink operations, explaining that "[c]odetermination is not the theory of the [NLRA]. The company decides its scale of operations. The union has no say ...."126 Under this rationale, the only question the

119 See Nielsen II, 977 F2d at 1170-71.

120 See text accompanying notes 67-72.

121 See Nielsen II, 977 F2d at 1170-71. See also text accompanying notes 73-79.

122 Nielsen II, 977 F2d at 1171.

${ }^{123}$ Judge Posner, author of the Nielsen decisions, agrees that the NLRA prohibits parties from making false claims. However, not every possibility of a false claim requires the same safeguards. The risk that an inability-to-pay claim is false is substantial enough to impose a duty on the employer to disclose. The risk that a competitive disadvantage claim is false is much lower, and an employer therefore should not be required to substantiate. Conversation with Judge Richard A. Posner (memo on file with U Chi L Rev).

${ }^{124}$ Nielsen $I I, 977 \mathrm{~F} 2 \mathrm{~d}$ at 1170 . This argument relies on the premise that "financial trouble" does not include situations in which an employer "continue[s] losing business" but is still "profitable at one percent of current output." See id.

${ }^{25} \mathrm{Id}$.

${ }^{126}$ Id at 1170-71, citing First National Maintenance, 452 US at 676. 
union has the right to have answered is whether the employer can in fact afford to pay the wage the union has requested. ${ }^{127}$ Once management acknowledges that it can afford the wage, ${ }^{128}$ the union has all the information it needs (or is entitled to). ${ }^{129}$

\section{Harvstone/Nielsen: Applying False Analogies}

None of the rationales supporting the Harvstone/Nielsen doctrine holds up under close examination. Further, while this Comment agrees that First National Maintenance should inform the proper disclosure standard for competitive disadvantage claims, the Seventh Circuit's derivation of the Harvstone/Nielsen doctrine misapplies the rule from that case.

\section{Threats, needs, and wants.}

According to the Seventh Circuit, Truitt protects unions against impermissible "threats," and competitive disadvantage claims are not threatening. Thus, a union facing such a claim has all the information it needs in order to know whether to strike. Because it knows the employer can, in some sense, afford to pay the requested wage, a strike might not be futile. ${ }^{130}$

The union does not, however, have all the information it needs to make an informed decision; it has only the information it is apparently entitled to receive. For example, if an employer claims that it must cut wages in order to "stem the hemorrhage of its business,"131 the union may have no idea whether the statement is true or false. Claims that link an employer's demands to the financial health of the company threaten the union precisely because they raise the risk there will be no company at all if the union does not accede to the employer's demands. Further, an employer making the "hemorrhage" claim cannot in any

127 Id at 1171.

${ }^{223}$ It is unclear whether the employer must explicitly acknowledge its ability to pay. In Nielsen II, the court noted that "[i]f [an employer] disclaims poverty, it moots any request for information that would be relevant only if poverty were being claimed." 977 F2d at 1171 (emphasis added). In Harvstone, however, the court noted that the employers "never implied that they were financially unable, as opposed to unwilling, to meet the Union's demands." $785 \mathrm{~F} 2 \mathrm{~d}$ at 576. A competitive disadvantage claim might therefore contain an implicit disclaimer of poverty.

${ }^{129}$ Nielsen II, 977 F2d at 1171. To illustrate how the company moots a demand for information by conceding that it can pay the requested wages, the court analogized the union to a civil litigant in discovery who receives a stipulation instead of documents. Id.

${ }^{130}$ See text accompanying notes 106-113.

13i Nielsen II, 977 F2d at 1170. 
meaningful way be simultaneously claiming it is not "in any financial trouble." ${ }^{132}$ Both statements cannot be true. ${ }^{133}$ If the employer can make the union believe it is in financial trouble, its competitive disadvantage claim would be only slightly less threatening than an inability-to-pay claim.

Additionally, courts applying the Harvstone/Nielsen doctrine assert that competitive disadvantage claims are simply manifestations of an employer's disagreement with the union's position. Yet competitive disadvantage claims are typically stated as needs rather than wants. For example, a court found a competitive disadvantage claim where the employer said that "concessions were needed in order to 'be competitive' and 'survive in today's market."'134

Just as with inability-to-pay claims, when an employer claims competitive disadvantage it asserts that it "cannot" pay the requested wage without dire consequences. The urgency of the need falls off when an employer claims that while it can pay now, it will lose business and lay off workers. This does not, however, transform a need into a want. In contrast, when an employer says that it would like to make more money or that it wants to be more competitive, it does not link its position to a prediction about the future of the enterprise. While such claims may represent serious bargaining positions, they are more likely to be interpreted as "puffing" than as a threat.

There is a crucial difference between an employer's assertion that the union's demands are unreasonable and the assertion that accepting the demands would be economically irrational. When an employer states that it needs a concession in order to survive, either immediately or in the long-term, it intends its statement to be acted upon, and such statements should be made in good faith.

Moreover, contrary to the Seventh Circuit's implication, ${ }^{135}$ the NLRA may forbid persistent claims by management that it does not want to pay. While the NLRA does not require the parties to agree, it nonetheless prohibits the parties from coming to the table with a predisposition against reaching agreement. ${ }^{136}$

132 Id.

${ }^{133}$ The Nielsen II court did not actually deny this; it simply implied that whether the "hemorrhage" claim is true or not is irrelevant. Id at 1171.

134 Local 14534, 983 F2d at 244. See also Western Wirebound, 356 F2d at 89 ("[A] cut was necessary because of price cutting indulged in by competition.”).

135 See Nielsen II, 977 F2d at 1171.

${ }^{136}$ See 29 USC \$ 158(d). See also text accompanying notes 19-22. An employer cannot 
To the extent management's unsupported claim manifests such an intent, it is irrelevant whether the claim concerns a mandatory or non-mandatory subject. ${ }^{137}$ Repeated, but unsubstantiated, competitive disadvantage claims could be strong evidence of such predisposition.

\section{Misinterpreting the scope of First National Maintenance.}

The Seventh Circuit's application of First National Maintenance to competitive disadvantage claims improperly disregards that case's balancing test, assumes that such claims are actually "management decisions," and contradicts Truitt.

a) Neglecting the First National Maintenance balancing test. The Harustone/Nielsen doctrine incorporates a misinterpretation of First National Maintenance. The Seventh Circuit assumes that all decisions about the scale of operations lie outside the realm of mandatory subjects of bargaining. ${ }^{138}$ Yet in determining whether specific management decisions are mandatory or permissive bargaining subjects, First National Maintenance requires the Board and the reviewing court to determine whether the "benefit, for labor-management relations and the collectivebargaining process, outweighs the burden placed on the conduct of the business." ${ }^{139}$ When it decided that partial closings were not mandatory subjects of bargaining, the First National Maintenance Court noted that "labor costs may not be a crucial circumstance in a particular economically based partial termination."140 At the same time, it distinguished Fibreboard, which held the decision to subcontract work to be a mandatory subject, ${ }^{141}$ noting that "a desire to reduce labor costs" was especial-

mechanically repeat claims or wants (even if true), if this is merely "surface" bargaining. See NLRB v Reed \& Prince Manufacturing Co., 205 F2d 131, 135 (1st Cir 1953).

137 Employers need not bargain about non-mandatory subjects. However, an employer that consistently responded to union wage proposals by stating, "I don't want to pay that," without ever offering an alternative or stating a reason could be held to have failed to bargain in good faith.

${ }^{138}$ Compare First National Maintenance, 452 US at $686 \&$ n 22 (weighing the harms and benefits caused by giving the union a voice in particular management decisions), with Nielsen II, 977 F2d at 1170-71 (arguing that the union categorically has no say in the scale of the employer's operations).

${ }^{139}$ First National Maintenance, 452 US at 679.

140 Id at 685 .

141 Fibreboard, 379 US at 213. 
ly "suitable for resolution within the collective bargaining framework." 142

In a recent plant relocation case that raises issues under both First National Maintenance and Truitt, the Second Circuit held that an employer must not only bargain about its decision to transfer business from Connecticut to Georgia, Texas, and Mexico, but must also provide the union with information to back up its claim that it needed to make the transfer because of labor costs. ${ }^{143}$ Applying the First National Maintenance balancing test, the Second Circuit first noted that under Fibreboard, an employer must bargain about an economically motivated action that results in no change in basic business operations. ${ }^{144}$ Finding that the employer's decision was "motivated by a desire to reduce labor costs," and that such decisions are "particularly suited to resolution through the collective bargaining process," the court concluded that "the Company's course of conduct would not have been unduly hampered by bargaining." 145

When an employer has decided to scale back rather than close part of its operations, and where labor costs dominate the resolution of this issue, the First National Maintenance benefitburden test suggests that such management decisions are usually not insulated from bargaining. If wages are the basis for the company's decision to lay off workers and scale back operations, then, the Harvstone/Nielsen doctrine notwithstanding, Fibreboard and First National Maintenance seem to command that the union does indeed have a say in the decision.

b) Claims are not decisions. Assuming First National Maintenance applies to decisions about the scale of operations as well as to partial closings, it applies only to decisions. To invoke First National Maintenance, management should first have to claim it has made or is about to make a decision about which it need not bargain. Yet management cannot unilaterally decide to

${ }^{142}$ First National Maintenance, 452 US at 680, quoting Fibreboard, 379 US at 214.

${ }_{143}$ Olivetti Office U.S.A., Inc. v NLRB, 926 F2d 181, 188 (2d Cir 1991).

144 Id at 186, citing Fibreboard, 379 US at 213.

145 Olivetti, 926 F2d at 186 (internal quotations omitted). The Second Circuit has long construed Truitt as consistent with the Western Wirebound doctrine. See New York Printing Pressmen and Offset Workers Union No 51 v NLRB, 538 F2d 496, 500 (2d Cir 1976). Nonetheless, the employer in Olivetti asserted that it would not provide the information for fear of a breach of confidentiality. 926 F2d at 184, 188. The court held such "conclusory assertions" insufficient to defeat the obligation to substantiate its claim. Id at 188-89. 
reduce wages without first bargaining to an impasse, ${ }^{146}$ even if it might be able to unilaterally close 50 percent of its business and lay off half of its workers. At most, competitive disadvantage claims represent predictions about future business conditions, given certain assumptions about wages and other factors. Thus, an employer that makes a competitive disadvantage claim when it has not yet made any decision cannot appropriately claim the protection of First National Maintenance.

c) Implicitly overruling Truitt. Finally, if a competitive disadvantage claim in fact represents a management decision, an inability-to-pay claim presents an even stronger case for protection from substantiation because it implicates the "decision whether to be in business at all." ${ }^{147}$ In Nielsen II, the court reasoned that competitive disadvantage claims are about a company's scale of operations, ${ }^{148}$ but the same is true of inability-to-pay claims. In each case the employer links its financial condition to the wages it pays.

If First National Maintenance holds that management need never substantiate claims that link a potential decision to scale back operations with the level of wages, then inability-to-pay (as well as competitive disadvantage) claims must be insulated as well, a conclusion that would contradict Truitt. Nothing in First National Maintenance suggests that the Court intended to overrule Truitt, and no subsequent decision has so construed First National Maintenance.

\section{Controlled Disclosure: Redefining the Duty to SUBSTANTIATE}

Both precedent and policy considerations suggest that competitive disadvantage claims should be evaluated on a case-bycase basis, rather than through the unsatisfactory Western Wirebound and Harvstone/Nielsen approaches. This Comment proposes an intermediate disclosure standard: Management should have to back up competitive disadvantage claims if the Board finds substantial evidence that management has either lied during bargaining or come to the table unwilling to agree. However, the union may only use the information it gains to

146 See 29 USC \& 158(d).

147 First National Maintenance, 452 US at 677.

${ }^{148}$ See 977 F2d at 1170. 
substantiate management's claim. The Board should require management to release the information when management violates widely-held notions of good faith, but control the union's use of the information once disclosed.

\section{A. Determining Management's Good Faith}

\section{Relevance.}

Before inquiring into good faith in a particular context, the Board should determine whether the claim was relevant to bargaining. A relevant claim would be one on which the parties would reasonably rely during negotiations. Irrelevant claims induce no reliance, and thus need not be supported. In determining whether a claim was relevant, the Board must inquire into how management intended the claim to be taken, and how the union might rationally have interpreted it. The Board should determine whether management intended the union to act on its claim, and whether a reasonable union would have based its actions on the accuracy of the claim.

\section{Predisposition and honesty.}

Once the Board finds that the claim is relevant, it should determine whether the claim was made in good faith. ${ }^{149}$ To determine if the employer came to the negotiations with a predisposition not to agree, the Board should consider whether the claim was repeated mechanically, without any offer of substantiating evidence. To determine if the employer's refusal to substantiate the claim suggests untruth, the Board should consider: (1) whether the employer has an economic interest in supporting the claim; (2) whether substantiation of the claim might force bargaining about.non-mandatory subjects such as decisions about the future of the business; and (3) whether the information might be used to embarrass the employer or to delay negotiations.

These "truthfulness questions" draw their power from the economic forces acting on the employer. First, since an employer wants to pay wages as low as possible, it has an incentive to seek concessions from the union. The union likewise has an incentive to push for wages as high as possible. An employer might honestly believe, for example, that current wages are too high or that the union's requested increase would be too large. Such conces- 
sions are more likely if the employer supports its claim. Thus, an employer's failure to back up a claim when substantiation would be in its best economic interest provides probative, but not dispositive, evidence of untruthfulness.

Second, an employer might legitimately refuse to back up an accurate claim when it reasonably fears that the union would misuse the information. For example, in Sign and Pictorial Union Local $1175 v N L R B$, the union alleged that strike replacements were receiving higher wages than strikers and requested wage information, which would have included the names of replacements. ${ }^{150}$ Fearing that the replacements would be harassed, the employer refused to provide the information, and the court upheld the Board's decision. ${ }^{151}$ On the other hand, if the union is unlikely to misuse the information, there is less reason to withhold it-and therefore some reason to suspect the veracity of the claim.

If the Board determines that the claim is untrue or a possible stalling tactic, it may require substantiation. In making its determination, the Board should review an employer's financial information in camera before requiring disclosure. This is not a burdensome requirement, and it will facilitate the resolution of the parties' dispute through informal discussions. Indeed, the vast majority of labor disputes are settled by means of informal discussions among representatives of the Board, the employer, and the union. ${ }^{152}$

Under the controlled disclosure approach, then, financial information lies in the exclusive province of management-unless management uses the information improperly. Thus, if management uses the information as leverage for a false claim, the Board may order disclosure. This approach is consistent with the general rule that the scope of the duty to disclose financial information is limited to verifying claims. ${ }^{153}$

150419 F2d 726, 737-38 (DC Cir 1969).

151 Id at 738.

152 National Labor Relations Board, Fifty-Fifth Annual Report for the Fiscal Year Ended September 30, 1990 6-7 (US GPO, 1992). In fiscal year 1990, approximately 86 percent of all meritorious cases were settled through formal or informal agreements at the regional level, and another 7 percent were disposed by compliance with an administrative law judge's decision. The final 7 percent were contested before the Board.

${ }_{153}$ See text accompanying notes 39-40. 


\section{B. Reconciling Truitt and First National Maintenance}

The controlled disclosure approach reconciles the potential conflict between First National Maintenance and Truitt. Truitt held that an employer's obligation to disclose financial information must turn on the "particular facts" of each case. ${ }^{154}$ This language suggests that the Court rejected both the broad and the narrow per se rules for financial information disclosures, even if it did not spell out clearly how the Board should determine good faith in such cases.

The controlled disclosure approach thus reads Truitt to require that claims beyond inability-to-pay be supported. However, by requiring a case-by-case determination of good faith, the Court did not impose on employers the duty to back up every claim. Why did the Court limit the employer's duty to claims made in bad faith, given that it could have predicted that the effect of an unsupported claim on the union would likely be the same regardless of whether the claim was true or not? It is possible that the Truitt Court feared that management might abuse its right to withhold information and the union might abuse the information once it was disclosed.

Under this reading, Truitt is a compromise. Rather than endorsing either a broad or narrow rule, Truitt suggests an expectation that conditions will vary, sometimes allowing employers to make claims without substantiation, other times requiring substantiation in order to keep bargaining open. The Court focused on the bargaining process in general, rather than simply on the effect of a particular rule on the union's ability to make progress in negotiations. Further, the general requirement of good faith does not allow dishonest claims in the bargaining process. This interpretation implies that the Court wanted the Board to make the determination of whether a claim need be substantiated, rather than allowing the union to force-or the employer to block-disclosure. ${ }^{155}$

The controlled disclosure approach also reconciles First $\mathrm{Na}$ tional Maintenance with Truitt. The First National Maintenance Court reasoned that "[m]anagement must be free from the constraints of the bargaining process to the extent essential for the

154351 US at $153^{\circ}$.

155 The Western Wirebound standard holds that the union should be able to force disclosure. See text accompanying note 90. Under the Harvstone/Nielsen doctrine, the veracity of competitive disadvantage claims is irrelevant, and management can prevent disclosure in such cases. See text accompanying notes 122-23. 
running of a profitable business." ${ }^{\text {156 }}$ The risk that the union will misuse information extends beyond simple harassment and delay. The union might second-guess the employer's bargaining position or press for even higher wages after receiving substantiating financial data. ${ }^{157}$ Forcing an inquiry into the employer's good faith before requiring disclosure places the Board under an affirmative obligation to assess the risk of union second-guessing and harassment. Even where an employer's claim was made in bad faith, the Board would be required to tailor its disclosure order to account for the risk of union misuse. ${ }^{158}$

By requiring case-by-base inquiries, the controlled disclosure approach protects employers and unions from each other's misuse of financial information. If an employer makes a claim in bad faith, it must substantiate. However, the union can only use the information to verify the claim-it may not, for example, base a strike decision on the information. If the union decided to receive the substantiating information, it could still strike later, but would have to prove it did not base the strike on the disclosed information. It is unlikely the union would risk this burden.

Consider a case where an employer claims that it needs a wage concession of $\$ 1.75$ an hour in order to remain competitive and the union asks for substantiating information. The employer voluntarily discloses a financial analysis substantiating its position, which shows a range of possible concession from $\$ 1.00$ to $\$ 2.50$. With the threat of a strike, the union might exploit the analysis by insisting on a concession of $\$ 1.25$. Since the union is only entitled to the information for the purposes of substantiating the employer's claim, and not to enable it to bargain more effectively, this use would be prohibited. In determining whether the union had misused the information, the Board would look at statements union representatives made to rank-and-file workers.

This notion is controversial. This Comment argues that some restraint on the union's use of the information is necessary to ensure consistency with First National Maintenance. However,

156 First National Maintenance, 452 US at 678-79.

157 The information a union requests may itself be evidence of an intent to harass the employer or otherwise interfere with the bargaining process. For example, in Nielsen II the court noted that the union asked for information on management perquisites-something outside the scope of mandatory bargaining. 977 F2d at 1169 .

158 The union's use of the information beyond simply substantiating management's claim might even be seen as a punishment of the employer. The Board has no authority to penalize an employer; it can only order remedies that will make the workers whole. See NLRB v Strong, 393 US 357, 359 (1969). 
the Court has not addressed whether it would be an unfair labor practice for the union to use financial information to obtain a more favorable bargaining position on a mandatory subject. In NLRB $v$ Jacobs Manufacturing Co., a case cited in Truitt, the Second Circuit noted that the union would not be entitled to information that would allow it to second-guess management's decisions. ${ }^{159}$ This Comment argues that the Jacobs court's reasoning should be extended to cover the union's use of financial information after disclosure. ${ }^{160}$

The controlled disclosure rule thus balances the risks of both union and management abuse. Management should be subject to a rule that does not allow it to harass or delay, and the union should face a rule that will limit the permissible uses it can make of the information it receives. In this way, both parties internalize the cost of their own abuses-and thus face incentives to minimize such behavior.

The controlled disclosure approach may be more complicated to administer, because it requires an inquiry into whether the claim was honest or part of a predisposition not to reach agreement. According to one commentator, the Board and the courts would be spared this "onerous judicial task" if the Western Wirebound standard were adopted. ${ }^{161}$ This claim is true, however, only if one assumes compliance with the Western Wirebound rule. In fact, a recalcitrant employer would be able to delay disclosure with minimal penalty to itself even under a per se rule of substantiation. ${ }^{162}$ Additionally, while the Board's inquiry under either of the per se rules might be shorter, it must seek enforcement in the courts of appeal, ${ }^{163}$ and its decision is still subject to review. ${ }^{164}$ Since these latter concerns clearly exist under the controlled disclosure rule as well, the advantage of applying either of the per se rules seems minimal.

159196 F2d 680, 684 (2d Cir 1952) (holding the Board could not require an employer to produce proof that its "business decision" was right).

${ }_{100}$ In Truitt, the Court found that the Board's disclosure order was not burdensome, and so declined to rule on the scope of Board orders generally. 351 US at 1510.

${ }_{161}$ Note, 87 Mich L Rev at 2051 (cited in note 4).

162 Remedies under the NLRA have historically been insufficient to deter most employers who want to fight their unions. Textile Workers Union $v$ Darlington Manufacturing Co., 380 US 263 (1965), is a particularly notorious example. By the time all appeals had been exhausted and final judgment was entered, one-third of the employees were dead. See Summers, et al, Labor Law at $443-44$ (cited in note 23).

${ }^{163}$ See 29 USC \& 160(e).

${ }^{164}$ Any aggrieved party may file a petition for review of an order by the Board in the courts of appeal. See 29 USC $\S 160(f)$. 
Moreover, because this Comment's approach requires the Board to balance the possible risks of abuse in determining the scope of disclosure required, it may actually appear more fair to the parties from the outset than either per se rule and thus may encourage voluntary compliance. A rule that prohibits employers from lying or stalling and unions from harassing should be considered fair by both sides. An employer will be less likely to make a claim in bad faith once it knows that the Board will eventually find out the truth. Similarly, a union that knows that the Board will limit the substance and use of disclosures will make more reasonable requests.

If the parties agree on the level of disclosure beforehand, or if the dispute is settled informally, the Board can avoid cumbersome inquiries into good faith. The Western Wirebound approach, however, may belittle management's concerns and make employers more likely to obfuscate. At the same time, the Harvstonel Nielsen doctrine, by depriving unions of needed information, may lead workers to strike out of spite. While neither party may consider the Board a neutral forum, when the Board applies a rule both parties consider fair, the parties may feel less need to press claims in the first place. Even when they do, however, the polarizing effects and attendant risks of abuse under either per se rule justify the additional inconvenience that the controlled disclosure rule might cause.

\section{CONCLUSION}

Both employers and unions may misuse financial information. Requiring substantiation of all competitive disadvantage claims would give the union the power to bargain not only about wages, but also about basic management decisions. At the same time, never requiring substantiation would let management force the union to make choices based on false or misleading claims. Requiring a case-by-case finding that management's claim was made in bad faith before requiring the disclosure of substantiating information, and controlling the use of that information by the union, would minimize the risks of abuse by either party-thus preserving management autonomy while promoting collective bargaining. 

, 